\title{
The Enigma of Commoning in Precarious Times: A Critical Perspective on Social Transformation
}

\author{
Carl-Ulrik Schierup ${ }^{\mathrm{a}^{*}} \odot$, Aleksandra Ålund ${ }^{\mathrm{a}}$ \\ ${ }^{a}$ Professor Emeritus at REMESO, Linköping University, Norrköping, Sweden.
}

Received 07 April 2020; Revised 17 May 2020; Accepted 23 May 2020; Published 01 June 2020

\begin{abstract}
The article explores movements for social transformation in precarious times of austerity, dispossessed commons, and narrow nationalism. The authors contribute to social theory by linking questions by critics of "post-politics" to precarity studies on changing conditions of citizenship, labour and livelihoods. They discuss an ambiguous constitution of precariat movements in the borderlands between "civil" and "uncivil" society and "invited" and "invented" spaces for civic agency, and posit that contending movements of today are drawing intellectual energy from past movements for democracy, recognition and the common. The paper discusses the issue of an urban justice movement in Sweden emerging from the precariat in this formerly exceptionalist welfare state's most disadvantaged urban areas. With its vision of reconstructing commons with roots in the working class movement, it has put forward claims for an egalitarian and non-racial democracy while confronting politically grounded frames of institutional conditionality.
\end{abstract}

Keywords: Precarity; Social Transformation; Civil Society; Commoning; Neoliberalism.

\section{Introduction}

At the beginning of the 1990s, neoliberal globalisation could still be imagined as a fortunate final stage of history. Yet, this new great transformation of the economy and society came with the cost of a commodification of the commons, targeting all communal or common under the authority of states or civic communities, or as Bourdieu (1999) contends: "an immense political operation ... aimed at creating the conditions for realizing and operating ... a programme of methodical destruction of collectives". Under the banner of "flexibility" politics of precarity has posited contingent employment and fragmented livelihoods - without, security, protection and predictability - as a new global norm [1]. However, an extended condition of precarity has been accompanied by a contestative countermovement of the precariat querying commodification, and carrying emancipary imaginaries of "realisable utopias" [2]. It resonates with an emancipating reimagining of democracy and the commons. This may take different modalities at a historical juncture where the "subjective dynamics of denationalization at the heart of globalization have not yet dispensed with the declining national imaginary", and in which "both the global and national stimulate people's deep-seated understandings of community" [3]. It implicates that visions and practices, i.e. Imagineering for "realisable utopias", must be scrutinised in a perspective of discursive and institutional path dependency.

From this perspective, we relate - after an introductory perspectivation of commoning in a postpolitical age, and the ambiguous constitution of precariat movements in borderlands between "civil" and "uncivil" society - to the case of a Swedish neoliberal state's "justice movement" emerging from the precariat in this formerly exceptionalist welfare

\footnotetext{
* Corresponding author: carl-ulrik.schierup@liu.se

doi http://dx.doi.org/10.28991/HIJ-2020-01-02-02

$>$ This is an open access article under the CC-BY license (https://creativecommons.org/licenses/by/4.0/).

(C) Authors retain all copyrights.
} 
state's most disadvantaged urban areas. We ask whether it harbours a transformative potential towards an egalitarian and non-racial democracy and what are receptions of its imaginings and activism?

This is a question that needs to be posed in the context of a wider discussion on the prevailing political hegemony and its discursive and institutional framing.

\section{Methods}

Qualitative interviewing, participant observation, netnographic participation on social media, secondary sources. The authors have studied movements for urban transformation in Stockholm since the beginning of the 1990s.

\section{Theorizing an Epoch of Contention}

Trapped in a consensual hegemony of market driven "post-politics" [4], old political parties have deserted visions of solidarity, equality, and social justice, and are loosing popular legitimacy. This poses the challenge to social theory on how to "imagine and to theorise ... forms of collective political identity and agency that might lead to the creation of new, ethical and democratic political institutions and forms of practice" [5].

The concept of commoning is at the centre, conceived as "acts of mutual support, conflict, negotiation, communication and experimentation that are needed to create systems to manage shared resources" [6]. Practices of commoning rest on the principle that the relation between social groups and social and physical aspects of the environment envisioned as commons "shall be both collective and non-commodified - off-limits to the logic of market exchange and market valuations" [7]. Far from being a mere academic reinvention, the old idea of the commons, understood as loci of defiance against a new enclosure movement, re-emerged as central formula for movements across the globe, which during the last three decennia have struggled for alternatives to neoliberalism [8]. What "commoning" as social practice stands for, and what it could possibly be, has been theorised by numerous studies in the 1990s and 2000s, contending that "state" and "market" are not the only systems of governance possible. Fraser (2017), for one, posits an array of contemporary civic agency as a "tripple movement" in an ambivalent double bind in relation to, but which may also challenge, the double squeeze of market and state [9].

We have argued elsewhere that predicaments of the present's logic of market and related commodification of labour and livelihoods can be captured theoretically through a bifocal conception of precarity: as a structurallygrounded "condition" of dispossession, yet a springboard for "resistance" and emancipation as well [1, 10].

Precarity, as an increasingly widespread social condition of life and work, without security and predictability, encompassing imperatives of "flexibility", "availability", "multilocality" and compressed "mobility" across time and space, is a "constitutive element of the new global disorder, to which it is very functional" [11]. Precarious conditions of work and citizenship arrive in tandem with a transformation of a redistributive welfare state into a neoliberal "regulatory state". Seen from this perspective, the state is "not anymore ... the mediator or "the shield" protecting society from the tensions between capital and labour — through ... redistributive policies" [12]. It is a transformation by which innumerable new regulations are tailored to undermine citizenship, the capacity to mobilise collective resistance and to form political constituencies. It holds implications for the role of civil society. Renegotiated social contracts, signified by state marketisation and the expansion of "participatory governance", are matched by growing prominence of a reconfigured, professionalised and NGOised civil society, with a role as service providers rather than as a mobilising force in politics. It has been depicted in terms of a "stealth revolution" which spells the end of liberal democracy by casting its very moral reason and institutional foundations in the moulds of market rationality" [13].

In this hiatus it is essential to link questions posed by critics of "post-politics", concerning contingences for democracy and politics of civil society, to those of precarity studies, denoting the precariat as a potentially gamechanging political actor for the $21^{\text {st }}$ century. Socially insecure and identity-seeking segments of today's precarious populations are obviously being mobilised by neo-fascist gestations of a contemporary countermovement, ostensibly confronting neoliberal globalisation. Yet an alternative precariat movement which may represent a more challenging prospect seen from the perspective of the present dominant hegemonies, in both North and South, are potentially uplifting radically democratic and egalitarian alternatives from the margin to the centre [14]. It concerns a multifarious activism of movements with imaginaries of a deepened non-racial democracy and harbouring transformative vistas of commoning. At the dawn of the new millennium it has come in many varieties and at varying scales - the neighbourhood, the city, the "nation", the region and the globe.

Contrary to being conceived as footloose and without sense of history and identity, the imaginaries of today's contentious movements have alternatively been depicted as drawing intellectual energy from past movements for democracy, recognition and the common good. Milkman (2016) [15], for one, concludes that post-2008 movements in the United States-contesting a racialised and gender discriminatory precarity of work, livelihoods and citizenship - are fusing an intellectual heritage of the working class movements of the 1930s, centred on labour and class politics, with that of the "new social movements" of the 1960s and 1970s, focused on emancipation through the recognition of identity [9]. 
As Funke (2014) argues contestative movements of a global precariat - represented as history-cognizant and intellectually rooted - stand forth with potentially system-transformative dynamics. Funke designates a spectrum of movements, initiated by the Zapatist surge in the 1980s and, including the movements of the 2000s, constituting a "distinct and integrated arch of mobilisations"; a historically particular "epoch of contention". Although movements are diverse - and can be understood as distinct "cycles of protest", their commonality rests in a shared logic of claims for democratic participation. While diverging from both the "old" class-centred labour movement and parties, as well as the "new" movements of the 1970s, the dominant logic of contemporary movements has been to amalgamate core characteristics of both. This is a logic which can accommodate diversity and a "multiplicity of struggles and possible futures [of] loosely linked organizations, groups and movements" [16].

It is a theoretical baseline from which the emergence and development of a multitude of diverse movements and networks can be studied with an emphasisis of linkages, cooperation and coalition dynamics within civil society. In pursuing this endeavor we find it methodologically important to develop two, ostensibly dichotomic, twin concepts integratively: "Uncivil" versus "civil" society cum "invented" versus "invited" spaces.

\section{4. "Uncivil" versus "Civil Society"}

In scholarship on civil society, "uncivil society" figures habitually as an antonym with a moral-political tint of "uncivilised", associated with intolerance, violence, political extremism, undemocratic values and anti-modernism; an "evil twin" of a "civil society" imbued with democratic and liberal values [17]. In contrast, our ongoing research is informed by an alternative de-colonial scholarship defining "uncivil society" as a "politics of informal people" [18], initiating "molecular changes" by the inventive creation of informal commons; corporeal as well as digital. Yet, our understanding of "uncivil society" transcends a perspective of "defiance", positing it as activism for social justice and emancipation from the state of precarity, in terms of a progressive social transformation, potentially challenging the conditions that shape it [19].

This does not validate a simplistic ideotypical dichotomy contraposing a "bad" civil society, pursuing its state or market centred sectional interest within the orbit of established governance, to a "good" anti-systemic uncivil society pursuing democratic transformation opposing market and state interests. While mainstreamed NGOs have become key players in the expansion of market principles embedded in decentralized "public-business, civil society "partnerships" it is nevertheless important to recognize the persistence of a critical value driven activism [20]. At the same time, argues Neocosmos (2011), if the mode of rule in a marginalized uncivil society is such that it enables the distortion or extinguishing of the very meaning of citizenship, they "face extraordinary obstacles when they attempt a movement beyond their political place; for their political existence is outside the domain of rights" [21]. Hence, if they shall be heard as citizens, beyond circumspect spheres of informal commoning proponents of a contestative, but nonrecognised, uncivil society may be forced to seek "the mediation of trustees" - usually in the form of established NGOs speaking for them in state authorised spaces of civil society, involved in participatory governance - "for it is only there that the rule of law operates reasonably consistently".

This transversal dynamics between civil and uncivil society can be productively elucidated through application of the notions of "invited" and "invented" spaces, as they were developed by Faranak Miraftab (2004) [22]. She applies the notion of invited spaces in her analyses of local governance in Cape Town, South Africa. She defines invited spaces "as the ones occupied by those grassroots and their allied non-governmental organizations that are legitimized by donors and government interventions" [22]. Invented spaces, Miraftab points out, are in contrast those also occupied by the grassroots and claimed by their collective action, but directly confronting the authorities and the status quo. However, she stresses a need to avoid a rigid conceptual barrier between invented and invited spaces as grassroots strategies are flexible and in their collective actions move between these spaces in order to advance their cause. Miraftab criticises in line with this any approach operating with a rigid separation of informal political actions. She (2009) further discusses struggles for citizenship through the Gramscian notion of "hegemony", seen as related to normalised ideopolitical relations, and uses the notion of "counter-hegemony" to describe practices and forces that destabilize relations of power in neoliberal "inclusive governance". She illustrates how grassroots movements use the hegemonic system's political openings to determine their own terms of engagement and participation. Either through inventing new spaces or re-appropriating old ones or by moving between these spaces, grassroots movements employ counter-hegemonic practices in order to "expose and upset the normalized relations of dominance" [23]. Or spoken through a Gramscian terminology: They launch a "war of position". But, a hegemonic move of state authorities that institutionalizes participatory development can also result in de-politization of contestative activist movements, as their struggles are caught up in state-market led processes of "NGOisation".

This calls for a critical contextualisation of the icon of "civil society" as ideological tenet in austerity driven, incrementally unequal and racialised societies. The critical relevance of its vilified, but assumably more original, second self, "uncivil society", may appear obvious relating to "townships", "favelas" or "shanty towns" of the South and the racialised urban "ghettoes", "banlieus" or "förorter" of the North with numerous migrants and post-migrant 
generations among its most dispossessed, who inhabit culturally stigmatised, and economically and politically marginalised spaces. Here, the "state of exception" - theorised by Giorgio Agamben (2005) as an immanent condition of contemporary societies through which civil, political and social rights pertaining to citizenship are truncated by governments - can be observed to rule in the most "naked" forms. It is contingent on, as well as conditions, urban unrest in disadvantaged multi-ethnic communities across the global North and South. It constitutes a rule under which new activist political subjectivities and movements are shaped among the most disadvantaged. Yet, the post - (2008) crisis trajectory of anti-austerity precariat rebellions suggests that the outlaw status of contestative civic movements, in effect movements outlawed to the domain of "uncivil society" without the right to demand rights, has a bearing on the fate, opportunities and contingent strategies of contemporary precariat movements, more generally.

Indeed consecutive precariat mobilisations for democracy and the commons can be read as ending in "disaster" (e.g. Occupy Wallstreat, The Arab Spring, the democratic mobilisations in Turkey sparked in Gezi Park, Syriza's left populist challenge to "the Troika"); temporarily "defeated by ideological and media forces, by the police, and by the ruling institutions" [24]. Their stigmatisation as outlaws beyond the pale of a respectable "civil society", and the institutional (often violent) repression from which these and other post-2008 insurgent movements have repeatedly suffered in the North as well as the South - for example represented by militarized action and unconstitutional laws on public demonstrations directed against the Yellow Vests in France or anti-austerity activism in Chile - point at the value of integrating the idea of "uncivil society" into a wider theory of social movements and civic action in the global North as well as South. From this perspective, there is a need to develop a critical scrutiny of challenges and opportunities of alliance-building, and the dealings of movement relays potentially bridging the uncivil-civil divide and the gap between invented and invited spaces, between precarians of the most disadvantaged banlieus, favelas, barrios, townships and racialised so-called "ghettoes" and a wider, forcibly "flexibilised" and vulnerable, precariat in general.

\section{Activism under Siege}

Let us set out to illustrate the argument by relating to a social situation, the time and space ramifications of which we have been following in our ongoing research $[25,26]$. It is embodied in an urban rebellion, provoked by repellent police violence; riots that raged across Stockholm's most precarious, racially stigmatised multiethnic districts in May 2013. The fervent character of the revolt, matched historically only by clashes of working class rioters and police in the $19^{\text {th }}$ century [27], struck the Swedish political establishment with awe and took the international community with "blazing surprise" [28]. However, only three years later, in 2016, we found ourselves participating (as observers) at an event in the very same local Stockholm community of Husby, from where the 2013 riots started: the opening of a local "House of the People", named Folkets Husby (Husby of the People). This relates to past politics of commoning, embedded historically in numerous citizens driven community centres, the People's Houses originating at the turn of the $19^{\text {th }}$ century [29]; an essential cornerstone of Sweden's legendary labour movement. Yet, flying a logo, recalling the Zapatist imagination of a 'rainbow that is also a bridge' [30], branded Folkets Husby as product of a locallygrounded coalition spearheaded by Sweden's multitude of young, racialised, post-migrant subalterns - Megafonen (Swedish: Megafonen) - emerging invigorated out of the time-hole blasted by the 2013 Stockholm rebellion. Speaking truth to power earned Megafonen the status of an emblem of an incipient Swedish urban justice movement [25]: the socalled suburban movement, with connotations of the Swedish word for 'suburb', förorten, matching the social, cultural and racial inferences of the internationally more well-known French idiom of the banlieu. Megafonen's evocative slogan with anti-imperialist connotations, 'A united suburb will never be defeated!', denotes a platform for glocal solidarity.

In 2013, Megafonen was still treated in mainstream media as an ephemeral exponent of an untrustworthy 'uncivil society's' insurgent activism (e.g. direct action against gentrification and the sham renovations of public housing), and vilified for its efforts to publicly explain the wider structural-institutional causes and predicament of the Stockholm insurrection [26, 31]. Today the organisation has metamorphosed into a network of alliances led by young postmigrant 'organic intellectuals' with their backgrounds mainly in the Middle East and Africa León Rosales, 2017 \#8027. It includes alliances with organisations of civil society with roots in the Swedish labour movement, human rights movements, critical thinktanks, as well as with movements of the precariat in other parts of Europe, the United States, Latin America and Africa.

Imaginings of Husby's People's House, established after years of mobilisation by local inhabitans and organized civil society actors - in particular Megafonen - could be described as that of an 'invented space', contraposed to subordinated 'participation' of citizens within 'invited spaces' of neoliberal governance; which in Sweden, as elsewhere, tends to reproduce rather than challenge a post-political condition of suppressed, or appropriated, civic agency. It was aimed to represent a local hub for a multiplicity of autonomous commoning beyond the double squeeze of market and state. This includes, among other, building a local library of movement relevant literature, critical youth and adult study circles, councilling on social and judiciary matters. 
The People's House in Husby was by activists aimed to become a 'nursery' for 'organic' movement intellectuals, introducing young racialised post-migrant Swedes to critical antiracist and decolonial scholarship. As reimagineered commoning spaces of and for disadvantaged communities reinvented People's Houses in Sweden's precarious communities should constitute vital Oases of Organisation', posit Al-Khamisi, Rezai and Ishi Aidid, long standing community activists and authors of a report (2019) on achievements and future concerns of the People's House in Husby, and in Rinkeby, another among Stockholm's most disadvantaged urban neighbourhoods [32]. An ambitious commoning mission, here put forward, foresees the strengthening local communities' self-confidence, identity, and capacity to influence public-political decision making. This includes, among other: independent media-production; broadening the mission of People's Houses further in civic education in collaboration with universities and other centres of learning; strengthening networks of collaboration between People's Houses across local communities; boosting the houses' capacity as centres for broad collaborative networks of relevant actors, with power to influence strategic decisionmakers; extending a multitude of non-commodified border crossing meeting places targeted at strengthening anti-racist social solidarity across communities and generations. It implicates raising collective power to engage citizens in anti-austerity protests and public manifestations against, for example, privatisation of public housing and gentrification, and questioning a stigmatising media discourse. It involves consolidating shared integrated platforms for citizens' influence on education and the labour market.

In the report the new People's Houses are, moreover, projected to become hubs for turning jurisprudence into a popular educative subject. This links up with an innovating commoning experiment built by former activists of Megafonenr: The Academy for Social Movement Lawyers (Akademin för rörelsejurister). The academy constitutes an autonomous educational common for the training of 'social movement lawyers' which draws on the experience of Black Lives Matter in the United States as well as that of lawyers and movements linked to Brazil's favelas and South Africa's precarious townships. Principles for the Academy were first laid out in a major report in 2015 [32], in terms of crafting jurisprudence and the practice of lawyers into a proactive catalyst for social change in liaison with contending social movements. It is targeted at making inequality and precarious conditions of citizenship, livelihoods and work visible, and at defending the rights of groups with a truncated access to democracy and the judicial system. It addresses individuals' and communities' experience of precarity and discrimination in a context of excessive inequality and racism and engages committed lawyers in collaboration with social justice movements. It problematises normatively sanctioned relations of power between the judicial profession and precarious social groups, with the lives and conditions of which lawyers are intricately involved.

However, the case of Folkets Husby demonstrates a reality, conditioned by fund raising for its activities through public-civil society partnerships, which has resulted in financial dependency on municipality, state and in dominant presence and influence of established NGOs [33]. All this comes with conditions prioritising activities for the 'integration' of perceived deviant categories of the population represented as social problems in political and media discourse: potentially delinquent youth, traditionalist women and putatively dysfunctional parents. It relates to activities for individual empowerment subjected to prescribed norms, but with limited space for the mobilisation of contestative action [34].

Yet, the institutional and structural conditions that incited the rise of the suburban justice movement in the first place, do persist, and have been severely aggravated due to the Covid-19 crisis. It has affected the precarious urban communities unproportinately hard, suffering from layoffs in occupational ghettoes, and illicit rents in a housing market increasingly driven by transnational venture capital. These trends are likely to be further exacerbated by pending legislation (2020), stipulating market-driven rent setting and urban development schemes, breeding gentrification and eviction of poor families [35]. Other pending legislation aims at loosening regulations on employment security, likely to further exacerbate the precarity of labour and livelihoods of the most disadvantaged.

These and other concerns that originally mobilised Sweden's urban justice movement remain as topical as ever. They do incite a new surge of contestation following in the historical trails of acticism in the community of Husby. But the question remains, whether a People's House, as far as it is conditioned by dependency on funding by the very urban regime that grounds the precarisation of a racialised Swedish surburbia, could be a catalysator in this pursuit? There is no definite answer. The actual state appears to mirror Miraftaf's depiction of an oscillation of a contending activism between invented and invited spaces, with Folkets Husby developing into an invited rather than an invented space.

One illustrative case is that of the Social Centre, a member organisation of Folkets Husby, which engages activists, professionals, and CSOs, anchored locally and operating nationally and internationally. The Social Centre is based on a coalition of three organisations that, within the frame of Folkets Husby, provide free of charge legal advocacy and organise workshops on housing, judicial, labour and welfare issues: The People's Movement Lawyers offering counselling on migration law, labour law, and family law; SAC Syndikalisterna, a leftist labour union, offering councelling and support concerning work under substandard conditions; Ort till Ort (Community to Community), member of the European Action Coalition of housing activists, offering councelling and aid to households exposed by evictions and inflated rents connected with sham renovations. 
On the one hand, these three organisations create new, politically controversial, invented spaces of contestative activism in Stockholm, Sweden, and Europe through networking and alliance making across communities and organisational divides, aimed at directly confronting the structural-institutional drivers of precarity of citizenship, labour and livelihoods. On the other hand, Folkets Husby functions as an invited space, in the context of which the centre operates a subtle "war of position" on the margins of dominant NGOs and Public-Civil Society partnership, ever exposed to, but also challenging the unspoken institutional condition that they should not cross the line between councelling and political activism.

\section{Conclusion}

The suburban movement transpired as a new political subject in the 2000s through its focus on social justice, presence as a critical public voice in mass media, public manifestations, and consciousness-raising - while still following in the footprints of old popular movements as schools of democracy [25, 36]. It challenged the racist politics of a reactionary nationalist populism as well as the reforming hegemony management of a so-called "progressive neoliberalism", including the essentialising identity politics of movements of civil society embedded in it [37].

Megafonen's declared aim to struggle for a just and egalitarian society "without racism, sexism and class oppression" and for a participatory democracy echoes in a sense what was once, by the mid-1970s, a social democratic promise of a progressive social transformation [38]. Yet, it resounds as pioneering in post-political times of neoliberal precarity. Moving forward through the past it also evokes qualities similar to the legendary Rainbow Coalition in Chicago of the late 1960s, which still stands out as exemplary today [39]. That is: a community mobilization embodying the intersectionality of race, class and gender, fusing variable forms of identity politics into one movement, amalgamated by one ideal form of identity; an identity transcending differences while focusing on commonalities, with precarity as its collective unifier.

Organizations like Megafonen continue to forge trans local alliances with other civil society actors and articulate goals and visions in broad public contexts. We have discussed their visions of Houses of the People as "oases for organisation", with historical roots in the Swedish labour movement. Yet, as we have discussed, referring to the case of Folkets Husby, in the community of Husby from which the 2013 urban rebellion sprung, its establishment and activities have become conditioned by reliance on public financing focused on "integration" through individual empowerment and demands not to venture beyond what is acceptable to authorised civil society organisations. This is all set in the contingency of a wider social context shaped by politics of sustained austerity which is increasingly paired with a surging narrowly nationalist and racializing politics, in line with a general European and global drift.

In sum, the case of Megafonen, followed by similar goals of the Social Centre, as related above, illustrates the importance of being able to manoeuvre flexibly between invited and invented spaces.

Sweden's urban justice movement emerged as a potential heir to the nation's old popular movements. Reimagineering a realisable utopia under new conditions it has made alternatives for social transformation visible. This stands out as crucial in today's crisis of political legitimacy, exploited by a collusion of socially fragmenting neoliberal austerity and an exclusionary right-wing nationalism. But, in doing so, the activism of contemporary precariat movements also raises the issue of the conditionality of spatial forms of political struggle, local governance, and, consequently, the issue of institutionalisation. It faces us with challenges in terms of theory and empirical research. What is in the making? Co-optation, and appropriation by disciplinary governmentality? Or are we witnessing a "war of position" that might open up subtle transformative strategies for commoning, social justice, and a non-racial democracy?

\section{Funding}

We appreciate the research funding by FORTE, the Swedish Research Council for Health, Working Life and Welfare [grant number 2006-1524], by FORMAS [grant number 250-2013-1547], and by the Swedish Research Council [grant number 721-2013-885].

\section{Declaration of Competing Interest}

The authors declare that they have no known competing financial interests or personal relationships that could have appeared to influence the work reported in this paper.

\section{References}

[1] Schierup, C.U., and Martin B. J. (2016). Politics of Precarity: Migrant conditions, struggles and experiences. Leiden \& Boston (MA): Brill Academic Publishers, Leiden, Netherlands.

[2] Lambert, R. (2010). Unionism in One Country is no Longer an Option. A Response to Michael Burawoy's' From Polanyi to Pollyanna: The False Optimism of Global Labour Studies'. Global Labour Journal, 1(3): 387-392. 
[3] Steger, M. (2009). Globalisation and social imaginaries: the changing ideological landscape of the twenty-first century. Journal of Critical Globalisation Studies, 1(1), 9-30.

[4] Mouffe, Chantal. (2005). On the Political. Routledge, Oxfordshire, England, UK.

[5] Gill, S. (2000). Toward a Postmodern Prince? The Battle in Seattle as a Moment in the New Politics of Globalisation. Millennium: Journal of International Studies, 29(1), 131-140. doi:10.1177/03058298000290010101

[6] Bollier, D. (2015). "Commoning as a Transformative Social Paradigm." The Next System Project. Available online: http://www.thenextsystem.org/commoning-as-a-transformative-social-paradigm/ (accessed on 2 April 2019).

[7] Harvey, D. (2012). Rebel cities: From the right to the city to the urban revolution. Verso books, London, United Kingdom.

[8] Laval, C., and Pierre, D. (2005). Común. Ensayo sobre la revolución en el siglo XXI. Barcelona: Gedisa, Spain.

[9] Fraser, N. (2017). A Triple Movement? Parsing the Politics of Crisis after Polanyi. Beyond Neoliberalism, $29-42$. doi:10.1007/978-3-319-45590-7_3.

[10] Waite, L. (2009). A Place and Space for a Critical Geography of Precarity? Geography Compass, 3(1), $412-433$. doi:10.1111/j.1749-8198.2008.00184.x.

[11] Ricceri, M. (2011). Europe and social precarity-Proactive elements for system interventions. Precarity. More Than a Challenge of Social Security. Or: Cynicism of EU's Concept of Economic Freedom. Bremen: Europäischer Hochschulverlag, 49-67, Bremen, Germany.

[12] Sommer-Houdeville, T. (2017). Remaking Iraq: Neoliberalism and a System of Violence after the US invasion, 2003-2011, Doctoral dissertation, Department of Sociology, Stockholm University, Stockholm, Sweden.

[13] Brown, W. (2015). Undoing the Demos: Neoliberalism's Stealth Revolution. Zone Books, New York, United States.

[14] García, A., Óscar, and Martin, B. J. (2016). "Uplifting the masses? Radical left parties and social movements during the crisis." in Europe's Radical Left: From Marginality to the Mainstream?, edited by March L and D Keith. Rowman \& Littlefield International, London, United Kingdom.

[15] Milkman, R. (2017). A New Political Generation: Millennials and the Post-2008 Wave of Protest. American Sociological Review, 82(1), 1-31. doi:10.1177/0003122416681031.

[16] Funke, P. N. (2014). Building Rhizomatic Social Movements? Movement-Building Relays during the Current Epoch of Contention. Studies in Social Justice, 8(1), 27-44. doi:10.26522/ssj.v8i1.1037.

[17] Glasius, Marlies. (2010). "Uncivil society." In International encyclopedia of civil society, edited by Helmuth K. Anheier, Stefan Toepler, and Regina A. List. New York (NY) Springer: 1583-88.

[18] Bayat, A. (1997). The Quiet Encroachment ofthe Ordinary: The Politics ofthe" Informal People. Third World Quarterly, 18(1), 53-72.

[19] Hallward, P. (2014). Defiance or emancipation? On Howard Caygill' on resistance: A philosophy of defiance'. Radical philosophy, (183), 21-32.

[20] Mary, K. (2003). Global Civil Society: An Answer to War. Polity Press, 7, 15-18, Cambridge, UK.

[21] Neocosmos, Michael. (2011). "Transition, human rights and violence: rethinking a liberal political relationship in the African neo-colony." Interface: a journal for and about social movements 3(2): 359-99.

[22] Miraftab, F. (2004). "Invited and Invented Spaces of Participation: Neoliberal Citizenship and Feminists' Expanded Notion of Politics." Wagadu 1(Spring 2004): 1-7.

[23] Miraftab, F. (2009). Insurgent planning: Situating radical planning in the global south. Planning Theory, 8(1), 32-50. doi:10.1177/1473095208099297.

[24] Hardt, M. (2017). Multiple temporalities of the movements. tripleC: Communication, Capitalism \& Critique. Open Access Journal for a Global Sustainable Information Society, 15(2), 390-392.

[25] León Rosales, René, and Aleksandra Ålund. (2017). "Renaissance from the Margins: Urban Youth Activism in Sweden." In Reimagineering the Nation. Essays on Twenty First Century Sweden, edited by Aleksandra Ålund, Carl-Ulrik Schierup, and Anders Neergaard. Frankfurt am Main and New York (NY): Peter Lang: 351-74.

[26] Schierup, C. U., Ålund, A., \& Kings, L. (2014). Reading the Stockholm riots-a moment for social justice?. Race \& class, 55(3), 1-21. doi:10.1177/0306396813509191.

[27] Berglund, M. (2009). Massans röst: Upplopp och gatubråk i Stockholm 1719-1848, Doctoral dissertation, Stads-och Kommunhistoriska Institutet, Stockholms Universitet, Stockholm, Sweden.

[28] The Economist Newspaper. (2013). "A Blazing surprise." The Economist. June 1, 2013. Available online: https://www.economist.com/europe/2013/06/01/a-blazing-surprise (accessed on 2 April 2019). 
[29] Ståhl, Margareta. (2005). Möten och människor i Folkets hus och park. Atlas, Stockholm, Sweden.

[30] EZLN. (1996). "1st Declaration of La Realidad for Humanity and against Neoliberalism". For Schools Chiapas. From the mountains of the Mexican Southeast, San Diego, CA, USA. Available online: http://www.schoolsforchiapas.org/library/1stdeclaration-la-realidad-humanity-neoliberalism/ (accessed on 2 April 2019).

[31] Megafonen. (2013). "Megafonens program". Megafonen. Stockholm, Sweden. Available online: megafonen.com/om/politisktprogram/ (accessed on 15 July 2013).

[32] Al-Khamisi, R. (2017). "Movement Lawyers: The path toward social change through law - on power, civil society and the need for a new breed of lawyers." Stockholm: Arena Idé, Sweden.

[33] Kellecioglu, I. (2017). NGO Participation in Local Politics: A case study of Husby. Södertörn University, Stockholm, Sweden.

[34] Schierup, C., and Aleksandra Å. (2020). "Reinventing the People's House: Time, Space and Activism in Multiethnic Stockholm." Critical Sociology: 1-16.

[35] Polanska, D., Degerhammar, S., and Åse Richard. (2019). Renovräkt! : hyresvärdars makt(spel) och hur du tar striden. Stockholm: Verbal, Sweden.

[36] Sernhede, O., René León R., and Söderman, J. (2019). 'När betongen rätar sin rygg'. Ortenrörelsen och folkbildningens renässans. Gothenburg: Daidalos, Stockholm, Sweden.

[37] Fraser, N. (2016). Progressive Neoliberalism versus Reactionary Populism: A Choice that Feminists Should Refuse. NORA Nordic Journal of Feminist and Gender Research, 24(4), 281-284. doi:10.1080/08038740.2016.1278263

[38] Ålund, A., and Carl-Ulrik S. (1991). Paradoxes of Multiculturalism. Essays on Swedish Society. Aldershot: Avebury. Republished 2009 as E-Book on the REMESO, Linköpings University, Linköping, Sweden. Available online: http://liu.divaportal.org/smash/record.jsf?pid=diva2:213706 (accessed on 28 April 2019).

[39] Williams, Jakobi E. (2013). "The Original Rainbow Coalition: An Example of Universal Identity Politics." Tikkun Magazine Archive. Available online: http://www.tikkun.org/nextgen/the-original-rainbow-coalition-an-example-of-universal-identitypolitics (accessed on 2 April 2016). 